\title{
Pengembangan Wawasan Multikultural Madrasah Ibtidayah Melalui Pembelajaran Pendidikan Agama Islam
}

\author{
Hamdani $^{1}$, Idi Warsah ${ }^{2}$ \\ Universitas Islam Negeri Fatmawati Sukarno Bengkulu \\ hamdani070768@gmail.com
}

\begin{abstract}
Received: 13 August 2021; Revised: 02 October 2021; Accepted: 28 December 2021
DOI: http://dx.doi.org/10.37905/aksara.8.1.581-586.2022
\end{abstract}

\begin{abstract}
Abstrak
Penelitian ini bertujuan untuk mengembangjan wawasan multicultural untuk guru dan peserta didik Madradah Ibtidayah melalui tingkah laku, dan pembelajaran pendidikan Agama Islam di Sekolah. Penelitian ini dilakukan di Madrasah Ibtidayah Kecamatan Sungai Serut Kota Bengkulu. Metode penelitian ini menggunakan pendekatan deskriptif kualitatif. Hasil temuan bahwa pengembangan wawasan multicultural dalam pembelajaran Pendidikan Agama Islam dilakukan melalui materi dan melakukan rekontruksi pengetahuan peserta didik. Melalui pendekatan sosio-kultural yang dilaksanakan oleh guru agama islam memberikan pengalaman siswa dengan menerapkan pendidikan yang berkeadilan dalam interaksi belajar melalui budaya dan struktur social dalam kegiatan belajar agama di sekolah.Selain itu pengajian materi pembelajaran
\end{abstract}

Key Word: Wawasan Multikultural, Kepemimpinan, Kreatif, Inovatif

\section{Pendahuluan}

Indonesia adalah salah satu bangsa yang majemuk. Secara umum kemajemukan bangsa Indonesia dapat dilihat dari dua sudut pandang yakni secara horizontal terdiri atas beragam suku dan ras, budaya, bahasa, nilai dan agama yang berbedabeda. Sementara dari segi vertikal dapat dilihat dari perbedaan tingkat pendidikan, ekonomi, pekerjaan, pemukiman dan sosial budaya. Usman Pelly dan Asih Menanti (2001:69)

Pendidikan multikultural menjadi salah satu concern dari Pasal 4 UU No. 20 Tahun 2003 tentang Sistem Pendidikan Nasional. Pasal ini menjelaskan pendidikan diselenggarakan secara demokratis, tidak diskriminatif dengan menjunjung tinggi hak asasi manusia, nilai keagamaan, nilai kultural dan kemajemukan. Institusi pendidikan bertanggungjawab mengkondisikan dan memotivasi peserta didik mengembangkan wawasan multikultural. Sudut pandang horizontal inilah yang menghadirkan istilah multikulturalisme. Meskipun demikian Indonesia memiliki landasan kuat yakni Pancasila yang menganut semangat kebhinekaan. Pancasila 
berkedudukan sebagai ideologi bangsa dan negara Indonesia serta sekaligus sebagai asas persatuan dan kesatuan sekaligus sebagai dasar filsafat Negara dan pandangan hidup bangsa.(Raharjo,M, 2007:123)

Pendidikan multikural sebagai wawasan dan sikap akan kemajemukan budaya baik dari latar suku bangsa, latar agama, latar profesi atau pekerjaan, latar daerah yang berbeda namun tetap menjunjung tinggi sikap toleransi. Sarana atau media yang dirasa cukup ampuh dalam mensosialisasikan pendidikan multikultural adalah lembaga pendidikan yakni sekolah, baik sekolah formal, informal maupun nonformal. Guru dan seluruh civitas akademika di sekolah harus turut berperan dalam menerapkan pendidikan ini. Apalagi dengan posisi berada pada sekolah yang terdiri atas etnis dan agama yang beragam. Sikap toleransi sebagai alternatif sikap yang harus ditonjolkan dalam keseharian di sekolah.

Guru (pendidik) yang merupakan bagian dari anggota lingkungan sekolah sangat berperan penting dalam menanam, menumbuhkan dan melestarikan keeragaman itu dengan selalu mengingatkan jiwa toleransi dan menghindari sikap diskriminatif. Melalui pendekatan dan model pembelajaran yang asyik, peserta didik (siswa) perlu diajak berdiskusi, berdialog bahkan bersimulasi bagaimana cara hidup saling menghormati dengan tulus dan toleran terhadap keberagaman agama dan budaya yang ada di tengahtengah masyarakat yang plural.

Peserta didik diajak berdialog untuk menimbulkan kepekaan terhadap aksi-aksi kekerasan yang ada, sehingga dapat menjadi feedback bagi sekolah untuk proses pembelajaran pendidikan multikultural. Juga sekolah perlu mendesain pendidikan multikultural ini agar tidak menjadi tanggungjawab guru mata pelajaran tertentu seperti mata pelajaran PPKn, Sosiologi dan Pendidikan Agama yang menjadi fundamental mata pelajaran berkarakter sikap spiritual dan sosial pada Kurikulum 2013 yang dipakai di negara Indonesia saat ini. Namun, goresan pendidikan multikultural harus terintegrasi dengan semua mata pelajaran. Desain ini diharapkan dapat menjadi wadah praktik atau simulasi siswa bahkan guru di tengah kehidupan yang plural.

Guru sebagai agen sosialisasi, fasilitator dan mediator dalam proses pendidikan multikultural harus memberikan penguatan, penegasan, dan motivasi agar menjadi suatu proses yang melekat dan tertanam kuat dalam pribadi siswa, sehingga bisa dikontruksikan menjadi pengalaman dan pengetahuan yang baru tentang nilai-nilai multikultural. Sadar keberagaman di tengah pluralitas yang dilandasi jiwa toleransi yang kuat, jujur, ikhlas dan menghargai orang lain atau kelompok lain, akan menjadi benih yang indah dalam perkembangan kehidupan berbangsa dan bernegara.

\section{Pengembangan Wawasan Multikultural dalam Pembelajaran}

Menurut Kamus Besar Bahasa Indonesia, (2008: 473) Pengembangan adalah suatu proses atau cara maupun perbuatan yang dilakukan secara bertahap namun teratur menuju sasaran yang dikehendaki sehingga terjadi peningkatan ke arah yang lebih baikJadi untuk mengembangkan wawasan peserta didik maka diperlukan waktu 
untuk berproses sehingga pemahaman tentang multicultural menjadi meningkat dari sebelumnya.

Menurut Kamus Umum Bahasa Indonesia (2008:45) wawasan dimaknai sebagai pandangan atau tujuan yang hendak dicapai setelah melakukan sesuatu. Adapun menurut Yusri,Muhammad (2008) Konsep wawasan ini dikaitkan dengan multikultural adalah keragaman, pluralitas, atau multikultur.

Adapun menurut Choirul Mahfud (2006: 75-79) "Multikultural" dari aspek kebahasaan mengandung dua pengertian kompleks yaitu "multi" berarti plural, "kultural" berarti kultur atau budaya. Asal kata multikultural, terdapat kesamaan dengan "Kebudayaan". Kebudayaan sebagai kultur dari bahasa latin adalah cultura; la culture yang salah satu pengertiannya; serangkaian kegiatan intelektual dalam sebuah peradaban.

Menurut Munandar, Arid,dkk (2019) Wawasan multikultural terbentuk melalui pengalaman-pengalaman berinteraksi dengan berbagai kalangan yang beragam latar belakang budayanya, dalam rentang waktu yang cukup lama. Dalam lingkungan seperti itu, kepekaan untuk melihat perbedaan dan persamaan akan terasah, sikap-sikap saling menghargai akan terbentuk, dan akhirnya tidak mudah mengalami gegar budaya ketika menemui hal-hal lain yang jauh berbeda dengan yang biasa dialaminya.

Menurut Hemamifitir (2019) Wawasan multikultural merupakan suatu paham tentang penghargaan, dan keadilan terhadap etnik minoritas baik yang menyangkut hakhak universal yang melekat pada hak-hak individu maupun hak-hak komunitasnya yang bersifat kolektif dalam mengekspresikan budayanya. Jadi pada dasarnya multikultural merupakan gagasan yang mengatur keberagaman dengan prinsip dasar pengakuan akan keberagaman itu sendiri.

Multikultural sebagai pengakuan dengan sadar bahwa sebuah negara atau masyarakat adalah beragam dan majemuk. Sebaliknya, tidak ada satupun negara yang hanya memiliki kebudayaan nasional tunggal. Hal ini mengandung pengertian perlunya upaya penerimaan dengan kesadaran terhadap realitas keberagaman, pluralitas, dan multikultural yang terdapat dalam kehidupan masyarakat. Jadi pengembangan wawasan multikultural berarti kemampuan peserta didik dalam menguasai sesuatu keragaman dan kemajemukan dengan pikiran. Karena itu belajar berati harus mengerti secara mental makna dan filosofisnya, maksud dan implikasinya serta aplikasinya, sehingga menyebabkan peserta didik dapat memiliki wawasan suatu situasi terkait dengan kondisi multikultural. Hal ini sangat penting bagi peserta didik yang belajar

\section{Metode Penelitian}

Pendekatan yang digunakan dalam penelitian ini yaitu menggunakan metode pendekatan deskriptif kualitatif. Dengan subjek penelitian yaitu guru dan peserta didik pada Madrasah Ibtidayah Kecamatan Sungai Serut Kota Bengkulu. Menurut Nazir (2014:43) metode deskriptif adalah suatu metode dalam meneliti status sekelompok 
manusia, suatu objek, suatu kondisi, suatu sistem pemikiran, ataupun suatu kelas peristiwa pada masa sekarang. Tujuan dari penelitian deskriptif ini adalah untuk membuat deskripsi, gambaran atau lukisan secara sistematis, faktual dan akurat mengenai faktafakta, sifat-sifat serta hubungan antar fenomena yang terselidiki. (Nazir, 2014) Sedangkan menurut Sugiyono (2019:18) metode penelitian kualitatif adalah metode penelitian yang berlandaskan pada filsafat postpositivisme, digunakan untuk meneliti pada kondisi obyek yang alamiah, (sebagai lawannya adalah eksperimen) dimana peneliti adalah sebagai instrument kunci, teknik pengumpulan data dilakukan secara trianggulasi (gabungan), analisis data bersifat induktif/kualitatif, dan hasil penelitian kualitatif lebih menekankan makna dari generalisasi.

\section{Hasil dan Pembahasan}

Pada Pendidikan madrasah, pengembangan Wawasan Multikultural melalui pembelajaran dikelas baik guru maupun siswa menggunakan langkah-langkah berikut:

\section{Budaya Literasi Kritis}

Literasi kritis diartikan sebagai integrasi keterampilan menyimak, berbicara, menulis, membaca, dan berpikir kritis. Literasi kritis sejatinya tidak hanya ditekankan kepada para peserta didik sebagai objek utama yang dibentuk dalam proses pembelajaran, tetapi juga kepada para guru sebagai sumber belajar dalam proses pembelajaran itu sendiri. Literasi kritis mampu memberikan sejumlah manfaat, antara lain menambah wawasan, mempertajam diri dalam menangkap suatu informasi, dan melatih kemampuan diri untuk menganalisis dan berpikir kritis terhadap suatu hal. Dalam konteks persoalan yang terjadi di kalangan sejumlah guru di tanah air saat ini, literasi kritis dapat menangkal benih radikalisme dan pandangan intoleransi yang mulai menjangkiti diri para guru. Literasi kritis dapat membentuk paradigma sekaligus mempertajam diri para guru dalam menangkap suatu informasi yang diterima dari berbagai sumber. Dengan demikian, para guru dapat mengkritisi secara cermat berbagai macam informasi yang tergolong baik dan buruk bagi kehidupannya maupun bagi kehidupan bersama. Dalam semangat belajar sepanjang hayat tersebut guru pun harus mampu menjadikan aktivitas membaca dan menulis sebagai suatu budaya yang tak terpisahkan dari dirinya. Melalui sikap belajar tersebut, potensi akal budi mereka pun akan semakin dilatih dan dikerahkan dari level yang rendah hingga mencapai level yang tertinggi. Dengan mencapai titik tersebut, setidaknya para guru mampu mengintegrasi keterampilan literasi kritis dalam hidupnya, yang mencakup keterampilan menyimak, berbicara, menulis, membaca, berpikir kritis, dan berperilaku sosial yang baik.Apabila guru sebagai pendidik memiliki integrasi keterampilan literasi kritis yang baik maka benih radikalisme dan pandangan intoleransi dapat diminimalisasi dan dibongkar sampai ke akarakarnya. Oleh karena itu, setiap guru perlu memiliki sikap long life education dan budaya literasi kritis dalam hidupnya, agar peserta didiknya pun mampu belajar dari 
sikap hidup para gurunya. Dengan begitu, benih radikalisme dan pandangan intoleransi dapat diberantas dalam stakeholders utama pendidikan yang mencakup para guru, peserta didik, dan materi pembelajaran.

\section{Budaya Toleransi}

Toleransi merupakan suatu sikap menghargai berbagai perbedaan dalam kehidupan sosial. Sikap toleransi perlu menjadi budaya dalam kehidupan para guru sebagai pendidik yang senantiasa memberikan nilai-nilai kehidupan bagi para siswanya. Hal tersebut dinilai penting karena budaya toleransi dapat mengikis berbagai prasangka dan kebencian di tengah perbedaan suku, agama, ras, dan antargolongan khususnya dalam ranah pendidikan. Salah satu cara dalam menumbuh embangkan budaya toleransi di kalangan para guru yaitu melalui dialog antarkelompok. Wujud konkret dari dialog tersebut yaitu melalui kegiatan live- in ke kelompok atau sekolah lain selama beberapa hari. Tempat live-in yang dituju merupakan tempat yang notabene latar belakang kehidupan di dalamnya agak berbeda dari yang dirasakan para guru lazimnya. Hal tersebut bertujuan agar para guru mampu mendapatkan keberlainan antara kehidupannya dan kehidupan kelompok lain. Melalui dialog antarkelompok, cakrawala pengetahuan para guru dapat terbuka sehingga mereka dapat menerima nilai-nilai kelompok lain yang berbeda dari kehidupan mereka lazimnya. Selain itu, dialog antarkelompok dapat membongkar pola hidup para guru yang cenderung selalu bergaul dengan sesamanya dalam lingkungan yang homogen. Dengan begitu, para guru dapat mengintrospeksi diri dan mampu menimbah pengalaman berharga dari setiap keberlainan yang dijumpai dalam hidupnya. Oleh karena itu, setiap keberlainan dalam kehidupan perlu ditanggapi dengan cita rasa persaudaraan yang tinggi demi terwujudnya kehidupan yang aman dan damai khusunya dalam ranah pendidikan.Sebagai seorang pendidik, sudah saatnya bagi para guru untuk berjuang memerangi berbagai hal buruk yang mulai menjangkiti dirinya, seperti benih radiklisme dan pandangan intoleransi. Dengan begitu, para peserta didik pun dapat belajar dari gurunya sebagai sumber belajar utama agar dapat menjadi pahlawan yang dapat memerangi berbagai persoalan konkret khusunya dalam dunia pendidikan dan sekitarnya.

\section{Kesimpulan}

Pengembangan wawasan multikultural melalui dimensi pemberdayaan budaya sekolah dan struktur sosial di Madrasah Ibtidayah Kecamatan Sungai Serut Kota Bengkulu yaitu melalui dua bentuk strategi yaitu terintegrasi melalui kegiatan pembelajaran pada seluruh mata pelajaran dengan jalan memasukkan nilai-nilai budaya pada silabus dan RPP yang diwujudkan pada proses pembelajaran maupun melalui kegiatan pengembangan diri baik itu kegiatan ekstrakurikuler maupun bimbingan konseling. Guru pendidikan agama islam terkadang belum 
mengimplementasikan pengembangan wawasan multikultural dalam arti meningkatkan pemahaman peserta didik tentang multikultural melalui pembelajaran karena kurang merespon perbedaan peserta didik khususnya melalui integrasi nilai dengan materi atau materi yang satu dengan materi lainnya yang terkait dengan multikultural. Guru misalnya kurang menghubungkan materi toleransi dengan contoh-contoh yang menjadi pengalaman peserta didik dalam berinteraksi dengan orang yang beragama nasrani atau agama lain di lingkungan rumahnya yang akhirnya pemahaman peserta didik. Begitu pula guru kurang membangun pengetahuan tentang multikultural dengan menggali contoh dari perbedaan multikultural, kurang penjelasan untuk mengurangi prasangka negatif terhadap perbedaan yang ada. Kendati demikian sudah terlihat perlakuan yang sama atau adil terhadap peserta didik dalam pembelajaran, dan telah melakukan pemberdayaan budaya sekolah dan struktur social yang dimiliki di madrasah Ibtidayahini misalnya dengan membiasakan budaya salam dan menghargai yang lebih tua seperti peserta didik dibiasakan mencium tangan guru ketika salaman, atau membungkuk ketika lewat di depan guru. Hal ini akan menjadi kebiasaan dalam kehidupan peserta didik sehari-hari.

\section{Daftar Pustaka}

Choirul Mahfud. 2006. Pendidikan Multikultural. Yogyakarta: Pustaka Pelajar.

Departemen Pendidikan Nasional.2008. Kamus Besar Bahasa Indonesia. Jakarta: Pusat Bahasa. Depdikbud.

J.S.Badudu. 2008. Kamus Umum Bahasa Indonesia. Jakarta: Pusat Bahasa.

Hemamifitira. 2019. Konflik Antar Etnis Melalui Penguatan Wawasan Multikultural. Jurnal Pendidikan Kewarganegaraan Volume 3, Nomor 1, Juni 2019. Web: https://journal.ikippgriptk.ac.id/index.php/kewarganegaraan/article/view/1092/9 15

Muhammad Yusri FM. 2008. Prinsip Pendidikan Multikulturalisme dalam Ajaran Agama di Indonesia. Yogyakarta: Jurnal Kependidikan Islam UIN Sunan Kalijaga Yogyakarta, Vol. 3, No. 2.

Mudija Rahardjo, Hermeneutika Gadameria. 2007. Kuasa Bahasa dalam Wacana Politik Gusdur. Malang: UIN-Malang Press.

Munandar, Aris,dkk. 2019. Model Pengembangan Wawasan Multikultural bagi Angkatan Kerja. Jurnal Pengabdian Masyarakat Bakti Budaya Vol. 2 No. 1 April 2019. Web : https://jurnal.ugm.ac.id/bakti/article/view/45029/pdf

Nazir, Moh. (2014). Metode Penelitian. Bogor: Ghalia Indonesia.

Sugiyono. (2019). Metode Penelitian Kuantitatif, Kualitatif R\&D. Bandung: Alfabeta.

Usman Pelly dan Asih Menanti. 2001.Teori-Teori Sosial Budaya. Jakarta: Dirjen Dikti 